
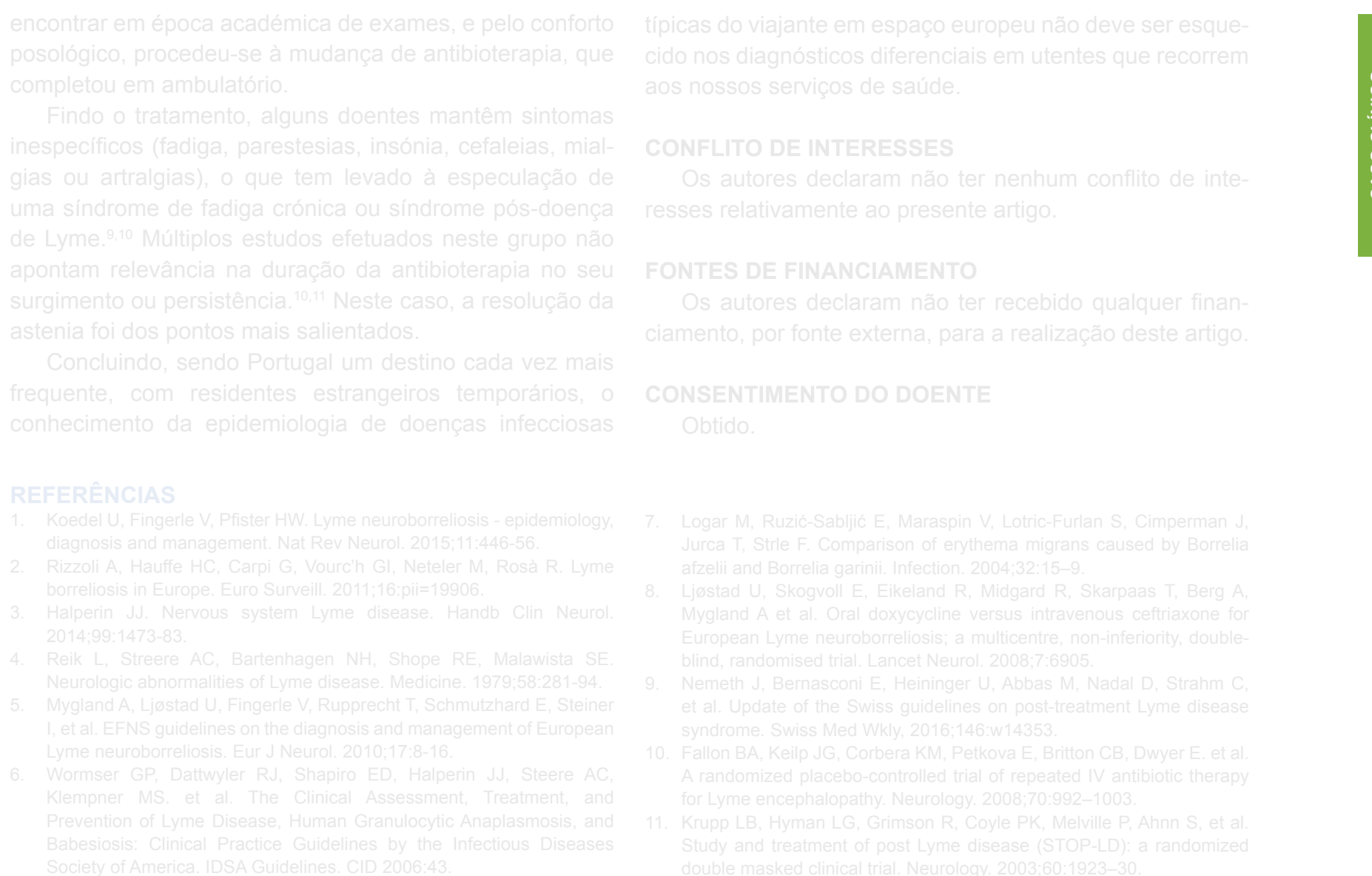

\title{
Severe Postpartum Coagulopathy Without Haemorrhage: A Case Report
}

\section{Coagulopatia Pós-Parto Severa Sem Hemorragia: Um Caso Clínico}

Muriel LÉRIAS-CAMBEIRO $\rrbracket^{1}$, Anabela RODRIGUES ${ }^{2}$, Inês TABORDA ${ }^{1}$, Filipa LANÇA ${ }^{1}$

Acta Med Port 2018 Sep;31(9):511-514 - https://doi.org/10.20344/amp.9795

\section{ABSTRACT}

Postpartum haemorrhage is an important health issue worldwide, and it can be caused by uterine atony, retained placental tissue, trauma or coagulation disorders. Although coagulopathy represents a rare cause, it is a significant contributor to postpartum haemorrhage with poor outcomes. Associated with high morbidity and mortality rates, postpartum haemorrhage demands prevention, prompt diagnosis and effective management. We describe a unique case of severe coagulopathy caused by underestimated blood loss during caesarean section without postpartum bleeding, in which transfusion requirements were thromboelastometry-guided. This case report depicts how an early multidisciplinary approach and patient-centred care in an obstetric emergency contributes to a positive outcome from a challenging situation, enabling the prevention of an imminent, catastrophic haemorrhage.

Keywords: Blood Coagulation Disorders; Blood Transfusion; Postpartum Hemorrhage; Thrombelastography

\section{RESUMO}

A hemorragia pós-parto é um importante problema de saúde a nível global, podendo ser causada por atonia uterina, placenta retida, trauma ou distúrbios na coagulação. Apesar de ser uma causa rara, a coagulopatia é um fator decisivo nas consequências negativas associadas à hemorragia pós-parto. Devido à sua elevada taxa de morbilidade e mortalidade, a hemorragia pós-parto exige prevenção, diagnóstico precoce e intervenção efetiva. Descrevemos um caso clínico raro de coagulopatia severa sem hemorragia no pós-parto,

\footnotetext{
1. Department of Anaesthesiology, Hospital de Santa Maria. Centro Hospitalar Lisboa Norte. Portugal.

2. Department of Immuno-Hemotherapy. Hospital de Santa Maria. Centro Hospitalar Lisboa Norte. Portugal.

$\triangle$ Autor correspondente: Muriel Lérias-Cambeiro. muriel@campus.ul.pt

Recebido: 15 de outubro de 2017 - Aceite: 05 de abril de 2018 | Copyright @ Ordem dos Médicos 2018
} 
causada por perdas hemáticas subestimadas durante a cesariana, e no qual os requerimentos transfusionais foram guiados por tromboelastometria. Este caso clínico reflete como uma abordagem multidisciplinar precoce, a uma emergência obstétrica, dá origem a um desfecho positivo numa situação desafiante, permitindo a prevenção de uma hemorragia catastrófica, iminente.

Palavras-chave: Hemorragia Pós-Parto; Transfusão de Sangue; Transtornos da Coagulação Sanguínea; Tromboelastografia

\section{INTRODUCTION}

Postpartum haemorrhage (PPH) is a major health issue affecting $2 \%$ of all parturient women worldwide. ${ }^{1}$ When $\mathrm{PPH}$, defined as blood loss superior to $500 \mathrm{~mL}$ in a vaginal delivery or $1000 \mathrm{~mL}$ in caesarean section, ${ }^{2}$ occurs in the first 24 hours it can be categorised as primary PPH. The secondary PPH refers to haemorrhage occurring from 24 hours to a time frame of 6 weeks. ${ }^{3}$ Most often linked with high morbidity and mortality rates, PPH demands prevention, prompt diagnosis and effective management. ${ }^{4}$

$\mathrm{PPH}$ can be due to uterine atony, retained placental tissue, trauma or coagulation disorders. ${ }^{3}$ According to aetiology, PPH severity differs. ${ }^{5}$ Controlling a PPH is quite challenging, and although several studies have been performed to address this issue, few high-quality evidence recommendations have been outlined. ${ }^{6,7}$ This case report highlights the relevance of early postpartum coagulopathy diagnosis in the successful prevention of primary PPH.

\section{CASE REPORT}

A healthy, 35-years-old, primigravida woman was admitted for induction of labour at 38 weeks plus five days gestation. She had had an uneventful twin pregnancy, supervised in our hospital following an in-vitro fertilisation procedure. Combined sequential spinal-epidural analgesia technique was performed 37 hours after prolonged labour induction with misoprostol, and analgesia maintained with $0.2 \%$ ropivacaine and sufentanil. However, the labour failed to progress beyond $7 \mathrm{~cm}$ dilatation and a caesarean section (CS) under epidural anaesthesia with $0.75 \%$ ropivacaine was carried out five hours later. The surgery was completed uneventfully, with blood loss estimated at $500 \mathrm{~mL}$ and crystalloid input of $1000 \mathrm{~mL}$. An intravenous bolus of $5 \mathrm{IU}$ oxytocin, followed by $15 \mathrm{IU}$ perfusion were also infused. Two living neonates were delivered (Apgar 9/10).

Ninety minutes after the delivery, a warning was given by the nursing staff due to patient's weakness and pale skin. Close monitoring revealed both haemodynamic stability and neither external nor internal bleeding, which was confirmed by the obstetrician. No relevant clinical signs, besides prolonged capillary refill time (superior to three seconds), were encountered. Blood samples for haemogram, platelet count, thromboelastometry (ROTEM ${ }^{\circledR}, \mathrm{TEM} \mathrm{GmbH}$, Munich, Germany) and arterial blood gases (ABG) were collected.

The ABG revealed haemoglobin $8.3 \mathrm{~g} / \mathrm{dL}$, arterial $\mathrm{pH} 7.39$, arterial $\mathrm{pCO}_{2} 25 \mathrm{mmHg}$, arterial $\mathrm{pO}_{2} 182 \mathrm{mmHg}$, arterial bicarbonate $18 \mathrm{mmol} / \mathrm{L}$, haemoglobin saturation $100 \%$, ionic calcium $1.17 \mathrm{mg} / \mathrm{dL}$, blood glucose $91 \mathrm{mg} / \mathrm{dL}$ and lactate $35 \mathrm{mg} / \mathrm{dL}$. Once the patient's previous haemoglobin level was $11.2 \mathrm{~g} / \mathrm{dL}$, consideration was given to a possible underestimated blood loss during CS. One unit of packed red blood cells and $1 \mathrm{~g}$ of tranexamic acid were immediately infused. Invasive blood pressure was monitored in addition to continuous electrocardiogram, pulse oximetry and diuresis, despite the absence of bleeding. In less than 15 minutes, ROTEM $^{\circledast}$ detected a massive coagulation disorder, which triggered our institution's Massive Bleeding Protocol activation (Fig. 1). Thromboelastometry subanalysis is presented in Table 1.

Based on ROTEM ${ }^{\circledR}$ analysis, the Immuno-Haemotherapy physician provided 1 platelet pool, $6 \mathrm{~g}$ of fibrinogen concentrate (Haemocomplettan ${ }^{\circledR}$, CSL Behring, Marburg, Germany), 2500 IU of prothrombin complex concentrate (Octaplex $^{\circledast}$, Octapharma PP, Vienna, Austria) and 4 fresh frozen plasma units which were administered through two largebore catheters (16 G). Another unit of packed red blood cells was supplied concomitantly with $20 \mathrm{~mL}$ of calcium gluconate $10 \%$, and a six-hour infusion of tranexamic acid $1 \mathrm{~g}$.

The patient maintained cardiovascular stability with no signs of haemorrhage during the event and the recovery phase. Final ROTEM $^{\circledR}$, collected 180 minutes after delivery, showed no relevant abnormalities and the ABG presented haemoglobin $8.0 \mathrm{~g} / \mathrm{dL}$ and lactate $10 \mathrm{mg} / \mathrm{dL}$ (Fig. 2).

To ensure close surveillance, the patient remained 24 hours in the post-anaesthesia care unit, uneventfully. At day five after delivery, the puerpera was discharged clinically well, with two healthy newborns.

\section{DISCUSSION}

Coagulopathy represents a rare cause of $\mathrm{PPH} .{ }^{8}$ The aetiology of coagulopathy related to $\mathrm{PPH}$ encompasses primary coagulation disorder or secondary causes such as
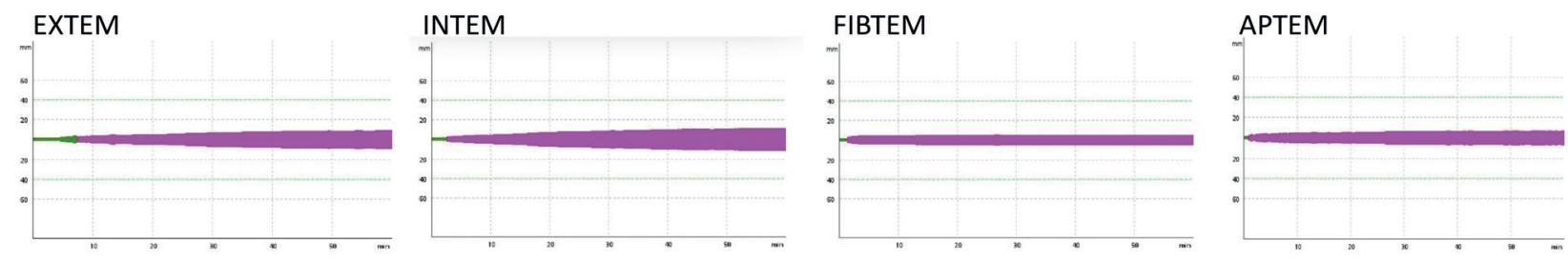

Figure 1 - Thromboelastometry $\left(\right.$ ROTEM $\left.^{\circledR}\right) 90$ min after delivery - severe coagulation impairment with coagulation factors, fibrinogen and platelets absent. 
Table 1 - Thromboelastometry $\left(\right.$ ROTEM $\left.^{\circledR}\right)$ analysis, 90 min and $180 \mathrm{~min}$ after delivery. Reference ranges, reported by Lange et al. ${ }^{13}$

\begin{tabular}{|c|c|c|c|c|c|c|c|}
\hline $\begin{array}{l}\text { Time after delivery } \\
\text { (minutes) }\end{array}$ & Assays & $\begin{array}{l}\text { CT } \\
(\mathrm{s})\end{array}$ & $\begin{array}{l}\text { CFT } \\
\text { (s) }\end{array}$ & $\begin{array}{c}\alpha \text { angle } \\
\left({ }^{\circ}\right)\end{array}$ & $\begin{array}{l}\mathrm{A} 10 \\
(\mathrm{~mm})\end{array}$ & $\begin{array}{l}\text { MCF } \\
(\mathrm{mm})\end{array}$ & $\begin{array}{l}\mathrm{ML} \\
(\%)\end{array}$ \\
\hline \multirow{4}{*}{90} & EXTEM $^{\circledR}$ & $\begin{array}{c}285 \\
(34-66)\end{array}$ & $\begin{array}{c}- \\
(44-154)\end{array}$ & $\begin{array}{c}- \\
(63-81)\end{array}$ & $\begin{array}{c}4 \\
(44-73)\end{array}$ & $\begin{array}{c}5 \\
(55-78)\end{array}$ & $\begin{array}{c}4 \\
(0-44)\end{array}$ \\
\hline & INTEM $^{\circledR}$ & $\begin{array}{c}152 \\
(98-225)\end{array}$ & $\begin{array}{c}- \\
(37-118)\end{array}$ & $\begin{array}{c}4 \\
(67-82)\end{array}$ & $\begin{array}{c}5 \\
(46-73)\end{array}$ & $\begin{array}{c}11 \\
(48-78)\end{array}$ & $\begin{array}{c}0 \\
(0-15)\end{array}$ \\
\hline & FIBTEM $^{\circledast}$ & $\begin{array}{c}77 \\
(31-59)\end{array}$ & - & $\begin{array}{c}- \\
(65-83)\end{array}$ & $\begin{array}{c}4 \\
(12-44)\end{array}$ & $\begin{array}{c}4 \\
(12-42)\end{array}$ & $\begin{array}{c}2 \\
(0-10)\end{array}$ \\
\hline & APTEM $^{\circledR}$ & $\begin{array}{c}55 \\
(31-71)\end{array}$ & $\begin{array}{c}- \\
(47-158)\end{array}$ & $(60-81)$ & $\begin{array}{c}5 \\
(43-72)\end{array}$ & $\begin{array}{c}5 \\
(56-78)\end{array}$ & $\begin{array}{c}8 \\
(0-14)\end{array}$ \\
\hline \multirow{4}{*}{180} & EXTEM $^{\circledast}$ & $\begin{array}{c}44 \\
(34-66)\end{array}$ & $\begin{array}{c}68 \\
(44-154)\end{array}$ & $\begin{array}{c}81 \\
(63-81)\end{array}$ & $\begin{array}{c}63 \\
(44-73)\end{array}$ & $\begin{array}{c}71 \\
(55-78)\end{array}$ & $\begin{array}{c}4 \\
(0-44)\end{array}$ \\
\hline & INTEM $^{\circledR}$ & $\begin{array}{c}112 \\
(98-225)\end{array}$ & $\begin{array}{c}60 \\
(37-118)\end{array}$ & $\begin{array}{c}78 \\
(67-82)\end{array}$ & $\begin{array}{c}63 \\
(46-73)\end{array}$ & $\begin{array}{c}72 \\
(48-78)\end{array}$ & $\begin{array}{c}4 \\
(0-15)\end{array}$ \\
\hline & FIBTEM $^{\circledast}$ & $\begin{array}{c}48 \\
(31-59)\end{array}$ & - & $\begin{array}{c}71 \\
(65-83)\end{array}$ & $\begin{array}{c}32 \\
(12-44)\end{array}$ & $\begin{array}{c}34 \\
(12-42)\end{array}$ & $\begin{array}{c}3 \\
(0-10)\end{array}$ \\
\hline & APTEM $^{\circledR}$ & $\begin{array}{c}48 \\
(31-71)\end{array}$ & $\begin{array}{c}63 \\
(47-158)\end{array}$ & $\begin{array}{c}81 \\
(60-81)\end{array}$ & $\begin{array}{c}64 \\
(43-72)\end{array}$ & $\begin{array}{c}72 \\
(56-78)\end{array}$ & $\begin{array}{c}6 \\
(0-14)\end{array}$ \\
\hline
\end{tabular}

CT: clotting time; CFT: clot formation time; A10 amplitude at 10 minutes; MCF maximum clot firmness; ML maximum lysis; (-) not measured
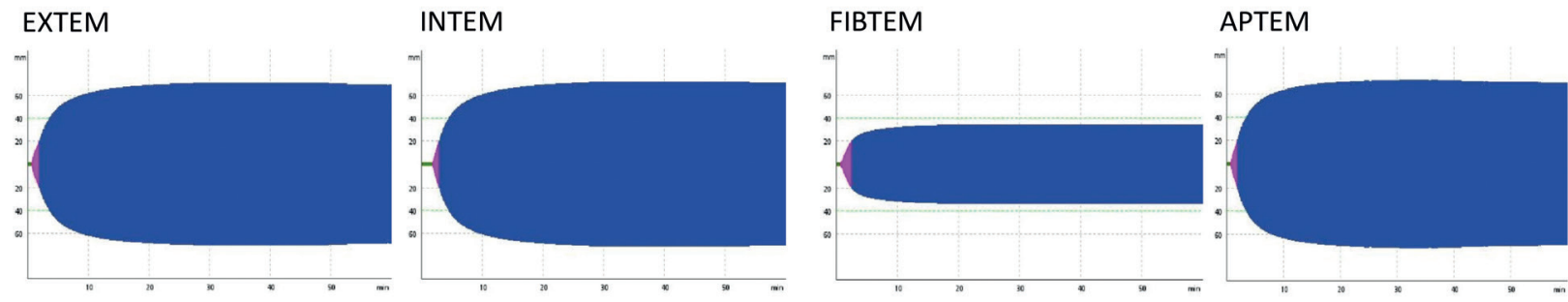

Figure 2 - Thromboelastometry $\left(\right.$ ROTEM $\left.^{\circledR}\right) 180$ min after delivery - normal exam with coagulation pathway preserved.

dilution coagulopathy, localised or disseminated consumption of clotting factors or platelets and increased fibrinolysis. ${ }^{9}$ Monitoring haemostatic impairment can be hard to accomplish and should rely on clinical observation, laboratory tests and point-of-care tests. Although no signs of bleeding or cardiovascular instability were observed in this case, clinical suspicions due to the presence of known PPH's risk factors, namely, CS after induced labour, prolonged labour and multiple pregnancy, ${ }^{10,11}$ led us to request a ROTEM ${ }^{\circledR}$ test. Laboratory parameters associated with $\mathrm{PPH}^{12}(\mathrm{Hb}<10$ $\mathrm{g} / \mathrm{dL}$ ) were absent in the initial laboratory evaluation before labour induction, and no coagulation abnormalities were observed. Point-of-care tests, as ROTEM ${ }^{\circledR}$, are gaining popularity because they assess the whole coagulation process in a quick and specific way. Peri-partum reference ranges for $\mathrm{ROTEM}^{\circledR}$, reported by Lange et $a l,{ }^{13}$ were compared with initial and after transfusion thromboelastometry, 90 and 180 minutes after delivery, respectively (Table 1). A severe coagulation disorder was detected as results began to become available, only 15 minutes after the sample was sent. This information allowed us to intervene rapidly in the prevention of an imminent, massive haemorrhage. Had results taken longer to be available, bleeding would probably have occurred. Moreover, ROTEM ${ }^{\circledR}$ parameters provide scope for a guided transfusion, minimising the risks inherent to haemocomponents and haemoderivatives replacement. A pre-existing institutional Massive Bleeding Protocol, as well as a close collaboration and interdisciplinary communication, were the fulcra of the success achieved. In this case, an underestimated intrapartum blood loss was the cause of coagulopathy.

This unique case report of severe coagulopathy reflects how an early multidisciplinary approach to an obstetric emergency results in a positive outcome, avoiding the imminent, catastrophic haemorrhage. It also emphasises the relevance of both an accurate evaluation of total blood loss and the adoption of a patient-centred strategy, based on clinical judgment, prevailing in the first instance over a preexisting diagnostic and therapeutic algorithm.

\section{ACKNOWLEDGMENTS}

The authors would like to thank Cristina Catarino for the help provided.

\section{PROTECTION OF HUMANS AND ANIMALS}

The authors declare that the procedures were followed according to the regulations established by the Clinical Research and Ethics Committee and to the Helsinki Declaration of the World Medical Association.

\section{DATA CONFIDENTIALITY}

The authors declare having followed the protocols in use at their working center regarding patients' data publication. 


\section{PATIENT CONSENT}

Obtained.

\section{CONFLICTS OF INTEREST}

All authors report no conflict of interest.

\section{REFERENCES}

1. World Health Organization. WHO recommendations for the prevention and treatment of postpartum haemorrhage. Geneva: WHO; 2012.

2. Oyelese Y, Ananth CV. Postpartum Hemorrhage: Epidemiology, Risk Factors and Causes. Clin Obstet Gynecol. 2010;53:147-56.

3. Walfish M, Neuman A, Wlody D. Maternal haemorrhage. Br J Anaesth. 2009; 103:i47-56

4. Carvalho M, Rodrigues A, Gomes M, Carrilho A, Nunes AR, Orfão R, et al. Interventional algorithms for the control of coagulopathic bleeding in surgical, trauma, and postpartum settings: recommendations from the Share Network Group. Clin Appl Thromb Hemost. 2016;22:121-37.

5. Guasch E, Gilsanz F. Massive obstetric haemorrhage: Current approach to management. Med Intensiva. 2016;40:298-310.

6. Mavrides E, Allard S, Chandraharan E, Collins P, Green L, Hunt BJ, et al. Prevention and management of postpartum haemorrhage. BJOG. 2016;124:e106-49.

7. Kozek-Langenecker SA, Ahmed AB, Afshari A, Albaladejo P, Aldecoa C, Barauskas G, et al. Management of severe perioperative bleeding: guidelines from the European Society of Anaesthesiology. Eur J Anaesthesiol. 2017; 34:332-95.

8. Collins P, Abdul-Kadir R, Thachil J. Management of coagulopathy

\section{FUNDING SOURCES}

None. associated with postpartum haemorrhage: guidance from the SSC of the ISTH. J Thromb Haemost. 2016;14:205-10.

9. Lange NM, Lancé MD, Groot R, Beckers E, Henskens YM, Scheepers HC. Obstetric Hemorrhage nad Coagulation: An Update. Thromboelastography, Tromboelastometry, and Conventional Coagulation Tests in the Diagnosis and Prediction of Postpartum Hemorrhage. Obstet Gynecol Surv. 2012;67:426-35.

10. Butwick AJ, Ramachandran B, Hegde P, Riley ET, El-Sayed YY, Nelson LM. risk factors for severe postpartum hemorrhage after cesarean delivery: case-control studies. Anesth Analg. 2017;125:523-32.

11. Girard T, Mortl M, Schlembach D. New approaches to obstetric haemorrhage: the postpartum hemorrhage consensus algorithm. Curr Opin Anesthesiol. 2014;27:267-74.

12. Owiredu WB, Osakunor DN, Turpin CA, Owusu-Afriyie O. Laboratory prediction of primary postpartum haemorrhage: a comparative cohort study. BMC Pregnancy Childbirth. 2016;16:17.

13. Lange NM, Rheenen-Flach LE, Lancé MD, Mooyman L, Woiski $M$, Pampus EC, et al. Peri-partum reference ranges for ROTEM $^{\circledR}$ thromboelastometry. Br J Anaesth. 2014;112:852-9. 